\title{
Contamination of Arsenic and Other Heavy Metals in Rhizospheric Soil
}

\author{
Khageshwar Singh Patel1,2*, Bharat Lal Sahu1, Shobhana Ramteke², Nitin Kumar Jaiswal3, \\ Laura Borgese ${ }^{4}$, Alessandra Gianoncelli ${ }^{4}$, Elza Bontempi ${ }^{4}$ \\ ${ }^{1}$ School of Studies in Chemistry, Pt. Ravishankar Shukla University, Raipur, India \\ ${ }^{2}$ School of Studies in Environmental Science, Pt. Ravishankar Shukla University, Raipur, India \\ ${ }^{3}$ Department of Chemistry, ITM University, Raipur, India \\ ${ }^{4}$ INSTM and Chemistry for Technologies Laboratory, University of Brescia, Brescia, Italy \\ Email: ${ }^{*}$ patelkhageshwarsingh@gmail.com
}

Received 16 August 2015; accepted 21 September 2015; published 24 September 2015

Copyright (C) 2015 by authors and Scientific Research Publishing Inc.

This work is licensed under the Creative Commons Attribution International License (CC BY).

http://creativecommons.org/licenses/by/4.0/

c) (1) Open Access

\begin{abstract}
The contamination of arsenic (As) and other heavy metal (HMs) in soil causes serious health hazard to the ecosystem. In this work, the contamination of As and other heavy metals (i.e. $\mathrm{Ti}, \mathrm{V}, \mathrm{Cr}$, $\mathrm{Mn}, \mathrm{Fe}, \mathrm{Ni}, \mathrm{Cu}, \mathrm{Zn}$ and $\mathrm{Pb}$ ) in rhizospheric soil of 14 plants of the severely As contaminated area of Central India is described. Among them, high content of As in the rhizospheric soils was observed, ranging from 0.22 to $4.60 \mathrm{~g} / \mathrm{kg}$ with mean value of $1.6 \pm 0.7 \mathrm{~g} / \mathrm{kg}$. The concentration variation, enrichment indices and toxicities of the metals in the soil are described.
\end{abstract}

Keywords

Arsenic, Heavy Metal, Rhizospheric Soil

\section{Introduction}

Arsenic and its compounds are especially potent poisons linking with a broad variety of neurologic, cardiovascular, dermatologic, and carcinogenic effects; including peripheral neuropathy, diabetes, ischemic heart disease, melanosis, keratosis, and impairment of liver function [1]. Chronic arsenic pollution has been now recognized as a worldwide problem, spreading in several countries of Asia, Australia, Africa, North and South America due to geogenic and anthropogenic emissions [2]-[7]. Severe arsenic contamination in environment of the central India $\left(21^{\circ} 6^{\prime} \mathrm{N} \& 81^{\circ} 2^{\prime} \mathrm{E}\right)$ has been reported [8]-[11]. High concentration of As and other HMs in the rhizospheric soils interfere the biological activities of plants [12]-[14]. The composition of rhizospheric soil is different from those

"Corresponding author.

How to cite this paper: Patel, K.S., Sahu, B.L., Ramteke, S., Jaiswal, N.K., Borgese, L., Gianoncelli, A. and Bontempi, E. (2015) Contamination of Arsenic and Other Heavy Metals in Rhizospheric Soil. American Journal of Analytical Chemistry, 6, 822829. http://dx.doi.org/10.4236/ajac.2015.610078 
of bulk soils due to biological activities [15]-[17]. Plants were reported for the phytoremediation of the HMs in soils [18]-[22]. In this work, content, enrichment and toxicity of As and other metals i.e. Ti, V, Cr, Mn, Fe, Ni, $\mathrm{Cu}, \mathrm{Zn}$ and $\mathrm{Pb}$ in rhizospheric soils of 14 common plants of the arsenic contaminated area, Koudikasa, CG, central India are described.

\section{Materials and Methods}

\subsection{Collection of Soil}

The sampling network for the soil collection is presented in Figure 1. A $100 \mathrm{~g}$ rhizospheric soil was collected in January, 2012 from the arsenic contaminated area, Koudikasa, Ambagarh Chowki block, Rajnandgaon, CG, India

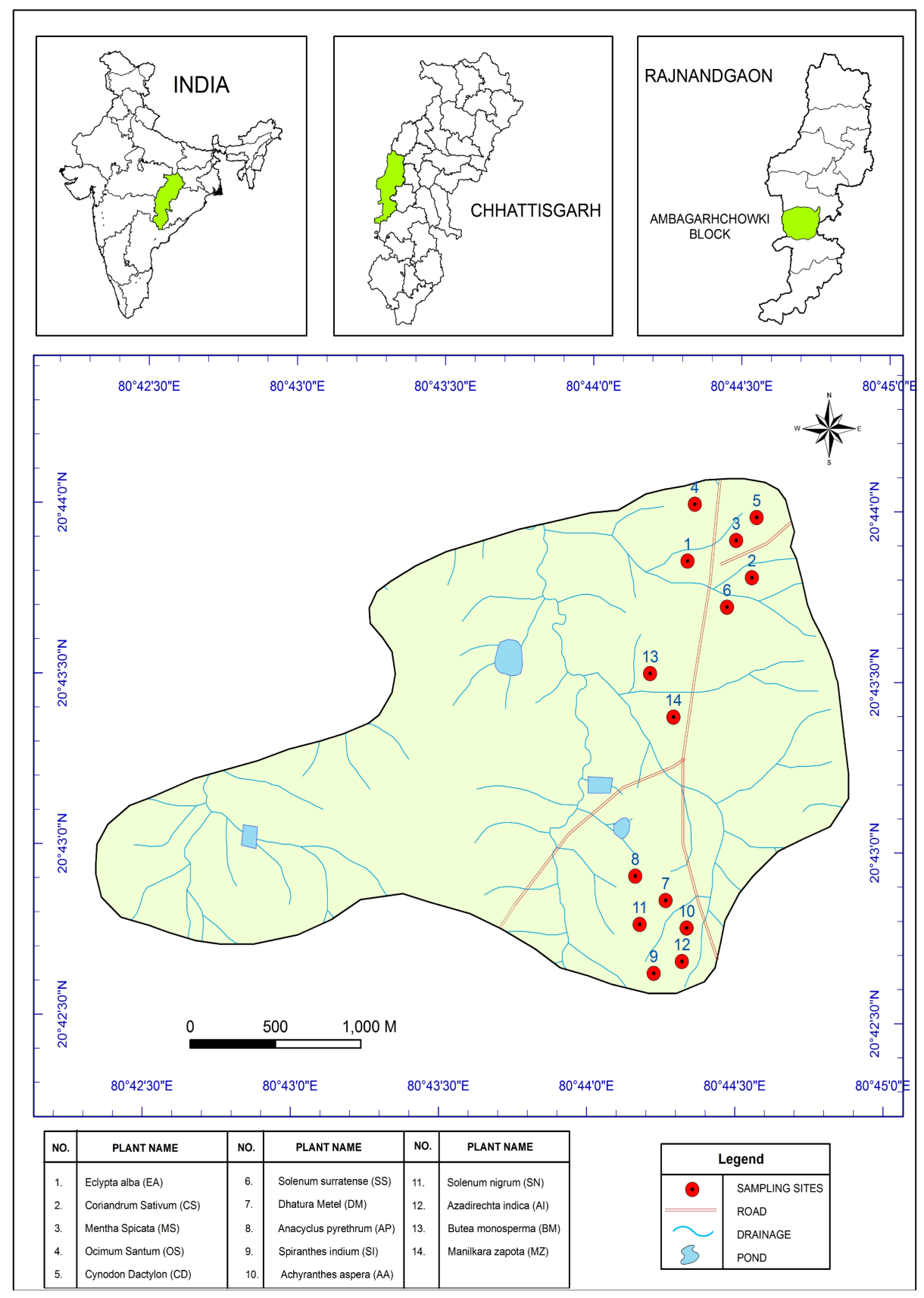

Figure 1. Representation of sampling locations in the map. 
$\left(21^{\circ} 6^{\prime} \mathrm{N} \& 81^{\circ} 2^{\prime} \mathrm{E}\right)$ as prescribed in the literature [23]. The bulk soil was also collected from the 14 sites for the comparison studies. The soil samples were kept in the polyethylene bottle and dried in an oven at $60^{\circ} \mathrm{C}$ for 12 hrs. The samples was milled and sieved out particles of $\leq 1 \mathrm{~mm}$ for the analysis.

\subsection{Soil pH}

The soil sample (10 g) was mixed with $20 \mathrm{~mL}$ of deionized water in a 100-mL conical flask and allowed to stand for overnight. The $\mathrm{pH}$ value of the extract was measured by Hanna $\mathrm{pH}$ meter type-HI991300.

\subsection{Soil Analysis}

The Bruker S2 Picofox TXRF portable spectrometer equipped with poly capillary lens and the X-ray beam was used for the analysis of the elements in soil. A suspended solution was prepared by mixing $10 \mathrm{mg}$ of soil sample with $10 \mathrm{~mL}$ of a water solution containing $1 \%(\mathrm{w} / \mathrm{v})$ triton in ultrasonic bath for $15 \mathrm{~min}$. Gallium was added to suspensions as an internal standard with a concentration of $10 \mathrm{mg} / \mathrm{L}$. For each measurement, $10 \mu \mathrm{L}$ of sample solution was sprayed on the quartz filter with subsequent drying. The X-ray source was focused on the filter for quantification of the elements. The peak area of the signal was computed. The three replicate measurements for each sample were carried out. The content of 14 elements (i.e. Al, P, K, Ca, As, Ti, V, Cr, Mn, Fe, Ni, Cu, Zn and $\mathrm{Pb}$ ) in each soil was analyzed. The standard soil sample (NCS DC 73382 CRM) was used for the quality control.

\subsection{Pollution Indices}

The pollution indices i.e. enrichment factor (EF), contamination factor (CF) and geo-accumulation index (GI) are used to determine element concentration in the soil samples with respect to the base line concentration. These relate the concentration of an element to a crustal element (e.g. Al) in the soil sample, and this ratio is then normalised to the ratio of those elements in the earth's crust. The following equations are used for the calculation of the pollution indices [24] [25].

$$
\begin{gathered}
\mathrm{EF}=\left\{\left[\mathrm{X}_{\mathrm{s}}\right] /\left[\mathrm{Al}_{\mathrm{s}}\right]\right\} /\left\{\left[\mathrm{X}_{\mathrm{e}}\right] /\left[\mathrm{Al}_{\mathrm{e}}\right]\right\} \\
\mathrm{CF}=\left\{\left[\mathrm{X}_{\mathrm{s}}\right] /\left[\mathrm{X}_{\mathrm{e}}\right]\right\} \\
\mathrm{GI}=\log 2\left(\left[\mathrm{X}_{\mathrm{s}}\right] /\left\{\left[\mathrm{X}_{\mathrm{e}}\right] \cdot 1.5\right\}\right)
\end{gathered}
$$

where, $\mathrm{X}_{\mathrm{s}}, \mathrm{Al}_{\mathrm{s}}, \mathrm{X}_{\mathrm{e}}$ and $\mathrm{Al}_{\mathrm{e}}$ are concentrations of metal and $\mathrm{Al}$ in the soil and earth crust, respectively.

\section{Results and Discussion}

The traditional and botanical name of the plants selected for the proposed studies is presented in Table 1 . The soil is yellowish colored with alkaline nature. The $\mathrm{pH}$ value of rhizospheric soil extracts $(\mathrm{n}=14)$ was ranged from 7.3 - 8.6 with mean value of $7.9 \pm 0.2$.

\subsection{Concentration of Metals in Bulk Soil}

High content of metals i.e. $\mathrm{K}, \mathrm{Ca}, \mathrm{Al}, \mathrm{Fe}$ and $\mathrm{Ti}$ was present in the bulk soil. Among them, Fe exhibited the highest content in the soil, followed by $\mathrm{Al}, \mathrm{K}$ and $\mathrm{Ca}$. The mean concentration of $\mathrm{Fe}, \mathrm{Al}, \mathrm{K}, \mathrm{Ca}, \mathrm{Ti}$ and $\mathrm{P}$ in the soil was found to be $203,114,75,52,31$ and $1.6 \mathrm{~g} / \mathrm{kg}$ respectively. The mean value of other HMs i.e. Mn, Cr, $\mathrm{Zn}, \mathrm{V}, \mathrm{Ni}, \mathrm{Cu}, \mathrm{As}$ and $\mathrm{Pb}$ in the bulk soil was 5.93, 0.88, 0.60, 0.51, 0.38, 0.36, 0.20 and $0.04 \mathrm{~g} / \mathrm{kg}$, respectively. The As content in the field soil of the study area was found to be much higher than in the soil of other countries i.e. Bangladesh, Nepal and China [1]-[7].

\subsection{Concentration of Metals in Rhizospheric Soil}

Similarly, elevated level of metals i.e. $\mathrm{Fe}, \mathrm{Al}, \mathrm{K}, \mathrm{Ca}$ and $\mathrm{Ti}$ in the rhizospheric soils was observed, ranging from, 115 - 322, 64 - 226, 26 - 147, 19 - 99 and 18 - $52 \mathrm{~g} / \mathrm{kg}$ with mean value of (at 95\% probability) $212 \pm 28,121 \pm$ 28, $87 \pm 19,56 \pm 16$ and $35 \pm 5$ g/kg, respectively. Other elements i.e. $\mathrm{Mn}, \mathrm{Cr}, \mathrm{P}, \mathrm{As}, \mathrm{Zn}, \mathrm{V}, \mathrm{Ni}, \mathrm{Cu}$ and $\mathrm{Pb}$ was 
Table 1. Description of plants.

\begin{tabular}{cccc}
\hline S. No. & Type & Traditional name & Botanical name \\
\hline 1 & Herb & Bhengraj & Eclypta alba (EA) \\
2 & Herb & Dhania & Coriandrum sativum (CS) \\
3 & Herb & Pudina & Oentha spicata (MS) \\
4 & Herb & Tulsi & Cynodon dactylon (CD) \\
5 & Herb & Doobgrass & Solenum surratense (SS) \\
6 & Herb & Bhaskatia & Dhatura metel (DM) \\
7 & Herb & Dhatura & Anacyclus pyrethrum (AP) \\
8 & Herb & Akartara & Spiranthes indium (SI) \\
9 & Herb & Kukurmuta & Achyranthes aspera (AA) \\
10 & Herb & Apamarg & Solenum nigrum (SN) \\
11 & Herb & Makoy & Azadirechta indica (AI) \\
12 & Tree & Neem & Butea monosperma (BM) \\
13 & Tree & Palas & Manilkara zapota (MZ) \\
\hline
\end{tabular}

found to be present in the rhizospheric soils at the moderate levels, ranging from 3.4 - 12.6, 0.78 - $3.01,1.2$ - 2.7, 0.2 - 4.6, $0.70-1.79,0.28-1.49,0.23-0.93,0.36-0.64$, and $0.0179-0.331 \mathrm{~g} / \mathrm{kg}$ with mean value of $7.4 \pm 1.5$, $1.69 \pm 0.42,1.6 \pm 0.2,1.6 \pm 0.7,1.07 \pm 0.16,0.71 \pm 0.16,0.58 \pm 0.16,0.48 \pm 0.05$, and $0.08 \pm 0.052$ g/kg, respectively Table 2 . Among them, a fair correlation $(\mathrm{r}=0.89)$ of the As with the $\mathrm{K}$ was observed, indicating their existence as $\mathrm{K}_{3} \mathrm{AsO}_{4}$ in the soil.

Remarkably high content of the As $(4.60 \mathrm{~g} / \mathrm{kg})$ was seen in the rhizospheric soil of Mentha spicata (MS), may be due to interaction of As with the carvone [26]. Significance content of V, $\mathrm{Zn}$ and $\mathrm{Pb}$ was observed in the in the rhizospheric soil of Solenum nigrum (SN), may be due to interactions of As with the glycoalkaloids [27]. Similarly, high content of Cr was seen in the rhizospheric soil of Achyranthes aspera (AA), and Cynodon dactylon (CD). The contamination of As and other HMs in the tree rhizospheric soil (TS), herb rhizospheric soil (HS) and bulk soil (BS), Figures 2(a)-(c). Arsenic in the TS and HS with respect to BS was extremely enriched (>8-folds). Other HMs i.e. V, Cr, Mn Fe, Ni, Cu, Pb and Zn were poorly to moderately enriched (>1 - >2) in the rhizospheric soils.

\subsection{Enrichment of Metals in Soil}

The concentration of metals i.e. As, Ti, V, Cr, $\mathrm{Mn}, \mathrm{Fe}, \mathrm{Ni}, \mathrm{Cu}, \mathrm{Zn}$ and $\mathrm{Pb}$ in the earth crust reported was 4.8, 3840, 97, 92, 774, 34900, 47, 28, 67 and $17 \mathrm{mg} / \mathrm{kg}$, respectively [28]. The mean EF value for As, Ti, V, Cr, Mn, $\mathrm{Fe}, \mathrm{Ni}, \mathrm{Cu}, \mathrm{Zn}$ and $\mathrm{Pb}$ in the rhizospheric soil was found to be 268, 8, 6, 14, 10, 9, 9, 14, 11 and 3, respectively, Table 3. Among them, As was extremely enriched in the rhizospheric soil. The EF, CF and GI value was ranged from 25 - 785, 42 - 958 and 4.9 - 9.3 with mean value of $268 \pm 129,343 \pm 157$ and $7.2 \pm 1.0$, respectively, Tables 3-5. Extremely high enrichment (>100) of As was observed in the rhizospheric soil of nine plant species: Butea monosperma (BM), Mentha spicata (MS), Spiranthes indium (SI) and Solenum nigrum (SN), respectively.

\subsection{Toxicities}

The allowable limits reported for the HMs i.e. As, Cr, Mn, Cu, Ni, Zn and Pb in the soil are 5, 200, 55, 50, 50, 400 and $70 \mathrm{mg} / \mathrm{kg}$, respectively [29] [30]. Among them, the concentration of As, Mn, Cu, Ni and Zn in the rhizospheric soil was found to be several folds higher than the reported values. The rhizospheric soils were contaminated with As at dangerous levels, and can cause toxic effects i.e. replacement of inorganic phosphate in biochemical reactions, inactivation of S-enzymes, distribution of $\mathrm{N}$-assimilation in plants, etc. [31]. 
Table 2. Distribution of metals in rhizospheric soil, g/kg.

\begin{tabular}{cccccccccccccccc}
\hline M & EA & CS & MS & OS & CD & SS & DM & AP & SI & AA & SN & AI & MZ & BM \\
\hline $\mathrm{As}$ & 2.81 & 2.32 & 4.60 & 3.72 & 0.30 & 1.99 & 0.26 & 0.96 & 0.67 & 0.22 & 0.48 & 1.35 & 0.32 & 3.00 \\
$\mathrm{~V}$ & 0.28 & 0.86 & 0.52 & 0.63 & 0.89 & 0.62 & 0.79 & 0.29 & 0.53 & 0.53 & 1.49 & 1.05 & 0.81 & 0.58 \\
$\mathrm{Cr}$ & 0.99 & 1.22 & 1.17 & 2.02 & 3.01 & 1.10 & 2.69 & 0.90 & 0.78 & 2.99 & 1.42 & 0.83 & 2.65 & 1.94 \\
$\mathrm{Mn}$ & 3.43 & 8.06 & 9.91 & 5.70 & 7.87 & 7.52 & 8.08 & 3.67 & 4.88 & 6.44 & 12.00 & 8.07 & 12.61 & 5.70 \\
$\mathrm{Ni}$ & 0.23 & 0.38 & 0.56 & 0.64 & 0.87 & 0.36 & 0.90 & 0.27 & 0.29 & 0.90 & 0.70 & 0.35 & 0.78 & 0.93 \\
$\mathrm{Cu}$ & 0.36 & 0.57 & 0.36 & 0.41 & 0.49 & 0.52 & 0.41 & 0.37 & 0.64 & 0.45 & 0.57 & 0.47 & 0.64 & 0.49 \\
$\mathrm{Zn}$ & 1.19 & 1.04 & 0.91 & 1.31 & 0.89 & 1.07 & 0.70 & 0.90 & 1.24 & 0.70 & 1.79 & 0.97 & 0.90 & 1.40 \\
$\mathrm{~Pb}$ & 0.116 & 0.042 & 0.071 & 0.080 & 0.048 & 0.065 & 0.030 & 0.032 & 0.019 & 0.020 & 0.331 & 0.041 & 0.144 & 0.085 \\
\hline
\end{tabular}

$\mathrm{EA}=$ Eclypta alba, $\mathrm{CS}=$ Coriandrum sativum, $\mathrm{MS}=$ Mentha spicata, $\mathrm{OS}=$ Ocimum santum, $\mathrm{CD}=$ Cynodon dactylon, $\mathrm{SS}=$ Solenum surrantense, $\mathrm{DM}=$ Dhatura metel, $\mathrm{AP}=$ Anacyclus pyrethrum, $\mathrm{SI}=$ Spiranthes indium, $\mathrm{AA}=$ Achyranthes aspera, $\mathrm{SN}=$ Solenum nigrum, $\mathrm{AI}=\mathrm{Azadirechta}$ indica, $\mathrm{BM}=$ Butea monosperma, $\mathrm{MZ}=$ Manilkara zapota .

Table 3. Enrichment factor (EF) of metals in rhizospheric soil.

\begin{tabular}{ccccccccccccccc}
\hline $\mathrm{M}$ & $\mathrm{EA}$ & $\mathrm{CS}$ & $\mathrm{MS}$ & $\mathrm{OS}$ & $\mathrm{DM}$ & $\mathrm{AA}$ & $\mathrm{CD}$ & $\mathrm{SS}$ & $\mathrm{AP}$ & $\mathrm{SN}$ & $\mathrm{SI}$ & $\mathrm{AI}$ & $\mathrm{MZ}$ & $\mathrm{BM}$ \\
\hline $\mathrm{As}$ & 337 & 375 & 785 & 604 & 40 & 25 & 40 & 431 & 125 & 58 & 171 & 203 & 32 & 526 \\
$\mathrm{Ti}$ & 6.7 & 10.2 & 10.5 & 6.5 & 5.8 & 6.2 & 8.4 & 15.3 & 5.7 & 6.0 & 9.0 & 9.8 & 5.0 & 6.3 \\
$\mathrm{~V}$ & 4.2 & 7.3 & 7.4 & 5.3 & 4.0 & 3.7 & 8.6 & 9.7 & 3.1 & 7.5 & 7.3 & 7.5 & 3.9 & 4.8 \\
$\mathrm{Cr}$ & 6.9 & 11.2 & 24.3 & 9.0 & 20.6 & 21.0 & 22.6 & 13.5 & 6.4 & 9.3 & 11.2 & 6.7 & 14.3 & 18.4 \\
$\mathrm{Mn}$ & 3.9 & 12.6 & 11.5 & 12.4 & 10.3 & 7.5 & 9.9 & 15.4 & 4.4 & 13.2 & 11.4 & 11.5 & 12.0 & 9.5 \\
$\mathrm{Fe}$ & 3.7 & 11.8 & 12.3 & 5.0 & 7.6 & 6.5 & 7.7 & 14.8 & 5.0 & 8.2 & 13.2 & 11.6 & 6.2 & 9.3 \\
$\mathrm{Ni}$ & 2.6 & 7.0 & 13.6 & 8.4 & 12.8 & 11.8 & 12.7 & 9.2 & 4.0 & 8.6 & 7.8 & 5.7 & 8.4 & 17.7 \\
$\mathrm{Cu}$ & 8.7 & 17.8 & 15.4 & 9.5 & 9.7 & 8.9 & 12.0 & 19.6 & 9.1 & 12.6 & 26.7 & 13.5 & 12.3 & 16.5 \\
$\mathrm{Zn}$ & 9.6 & 10.9 & 18.4 & 7.9 & 6.2 & 5.7 & 7.9 & 15.8 & 7.5 & 13.9 & 19.6 & 9.8 & 6.1 & 16.5 \\
$\mathrm{~Pb}$ & 4.0 & 1.8 & 4.7 & 2.5 & 1.1 & 0.7 & 1.8 & 4.2 & 1.0 & 10.5 & 1.3 & 1.7 & 4.0 & 4.2 \\
\hline
\end{tabular}

Table 4. Contamination factor (CF) of metals in rhizospheric soil.

\begin{tabular}{cccccccccccccccc}
\hline M & EA & CS & MS & OS & DM & AA & CD & SS & AP & SN & SI & AI & MZ & BM \\
\hline As & 583 & 479 & 958 & 771 & 63 & 42 & 63 & 417 & 208 & 104 & 146 & 281 & 67 & 625 \\
$\mathrm{Ti}$ & 11.6 & 12.9 & 10.3 & 10.3 & 8.9 & 10.5 & 13.2 & 14.7 & 9.5 & 10.8 & 7.6 & 13.7 & 10.3 & 7.5 \\
$\mathrm{~V}$ & 7.2 & 9.3 & 8.2 & 7.2 & 6.2 & 6.2 & 13.4 & 9.3 & 5.2 & 13.4 & 6.2 & 10.8 & 8.4 & 6.0 \\
$\mathrm{Cr}$ & 11.8 & 14.1 & 14.1 & 23.5 & 31.8 & 35.3 & 35.3 & 12.9 & 10.6 & 16.5 & 9.4 & 9.8 & 31.2 & 22.8 \\
$\mathrm{Mn}$ & 6.8 & 16.2 & 19.8 & 11.4 & 16.2 & 12.8 & 15.8 & 15 & 7.4 & 24 & 9.8 & 16.14 & 25.22 & 11.4 \\
$\mathrm{Fe}$ & 6.6 & 15.3 & 8.0 & 12.3 & 12.0 & 11.3 & 12.3 & 14.6 & 8.5 & 15.0 & 11.4 & 16.1 & 12.9 & 11.0 \\
$\mathrm{Ni}$ & 4.5 & 9.1 & 13.6 & 13.6 & 20.5 & 20.5 & 20.5 & 9.1 & 6.8 & 15.9 & 6.8 & 8.0 & 17.7 & 21.1 \\
$\mathrm{Cu}$ & 16 & 24 & 16 & 16 & 16 & 16 & 20 & 20 & 16 & 24 & 24 & 18.8 & 25.6 & 19.6 \\
$\mathrm{Zn}$ & 16.9 & 14.1 & 12.7 & 18.3 & 9.9 & 9.9 & 12.7 & 15.5 & 12.7 & 25.4 & 16.9 & 13.7 & 12.7 & 19.7 \\
$\mathrm{~Pb}$ & 7.1 & 2.4 & 4.1 & 4.7 & 1.8 & 1.2 & 2.9 & 4.1 & 1.8 & 19.4 & 1.2 & 2.4 & 8.5 & 5.0 \\
\hline
\end{tabular}




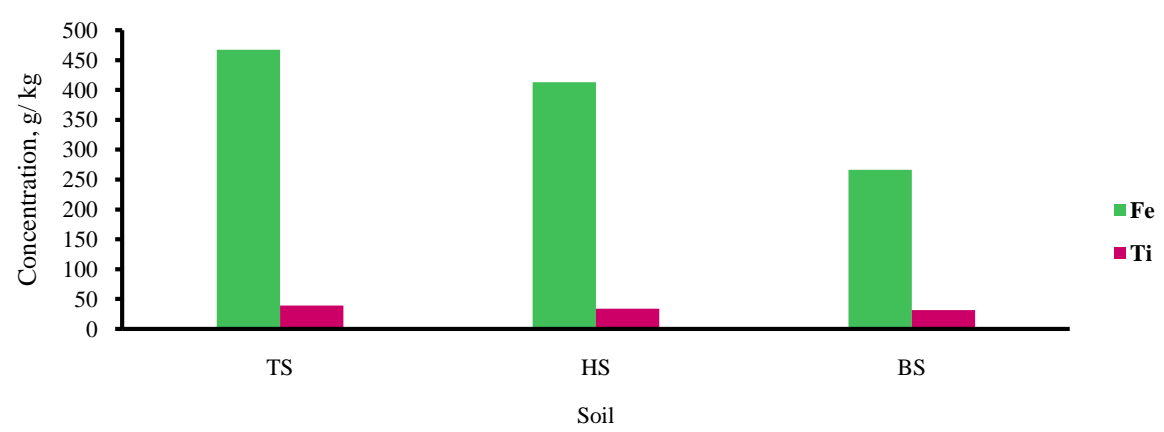

(a)

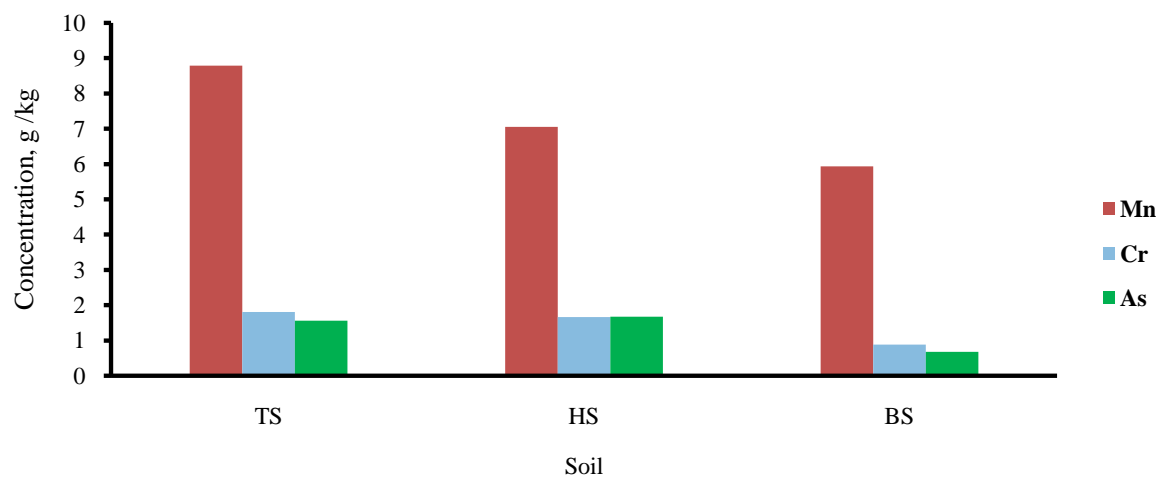

(b)

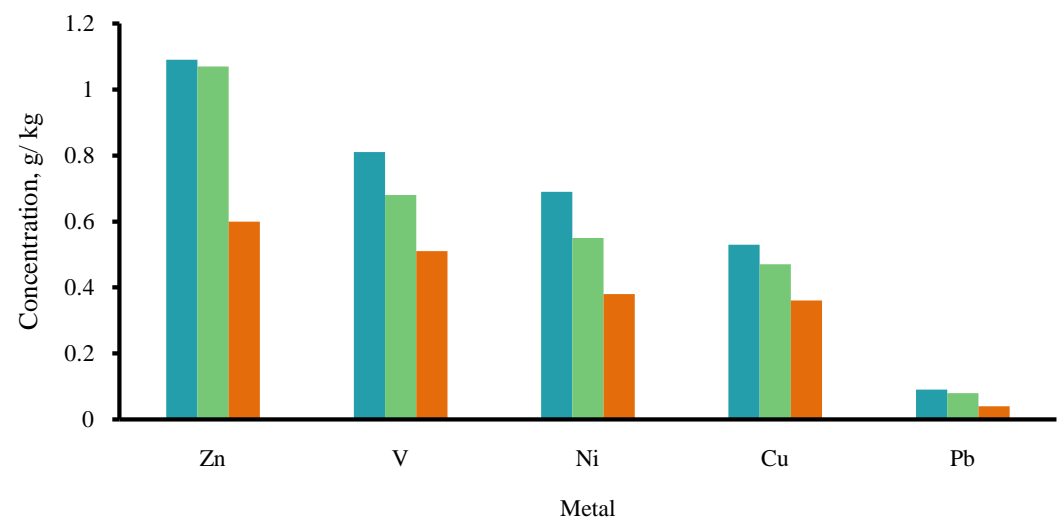

- TS

HS

-BS

(c)

Figure 2. Concentration of metals in soil: TS = Tree rhizospheric soil, HS = Herb rhizospheric soil, BS = Bulk soil.

Table 5. Geoaccumulation index (GI) of metals in rhizospheric soil.

\begin{tabular}{ccccccccccccccc}
\hline M & EA & CS & MS & OS & CD & SS & DM & AP & SI & AA & SN & AI & MZ & BM \\
\hline $\mathrm{As}$ & 8.6 & 8.3 & 9.3 & 9.0 & 5.4 & 8.1 & 5.2 & 7.1 & 6.5 & 4.9 & 6.1 & 7.6 & 5.5 & 8.7 \\
$\mathrm{Ti}$ & 2.4 & 2.7 & 2.5 & 2.6 & 2.6 & 2.6 & 2.8 & 1.6 & 1.7 & 2.7 & 3.2 & 3.1 & 2.7 & 2.3 \\
$\mathrm{~V}$ & 0.9 & 2.6 & 1.8 & 2.1 & 2.6 & 2.1 & 2.4 & 1.0 & 1.9 & 1.9 & 3.4 & 2.9 & 2.5 & 2.0 \\
$\mathrm{Cr}$ & 2.8 & 3.1 & 3.1 & 3.9 & 4.4 & 3.0 & 4.3 & 2.7 & 2.5 & 4.4 & 3.4 & 2.6 & 4.3 & 3.8 \\
$\mathrm{Mn}$ & 1.6 & 2.8 & 3.1 & 2.3 & 2.8 & 2.7 & 2.8 & 1.7 & 2.1 & 2.5 & 3.4 & 2.8 & 3.4 & 2.3 \\
$\mathrm{Fe}$ & 2.1 & 3.3 & 2.4 & 3.0 & 3.0 & 3.3 & 3.0 & 2.5 & 2.9 & 2.9 & 3.6 & 3.4 & 3.1 & 2.9 \\
$\mathrm{Ni}$ & 1.7 & 2.4 & 3.0 & 3.2 & 3.6 & 2.3 & 3.7 & 1.9 & 2.0 & 3.7 & 3.3 & 2.3 & 3.5 & 3.7 \\
$\mathrm{Cu}$ & 3.1 & 3.8 & 3.1 & 3.3 & 3.5 & 3.6 & 3.3 & 3.1 & 3.9 & 3.4 & 3.8 & 3.5 & 3.9 & 3.5 \\
$\mathrm{Zn}$ & 3.6 & 3.4 & 3.2 & 3.7 & 3.2 & 3.4 & 2.8 & 3.2 & 3.6 & 2.8 & 4.2 & 3.3 & 3.2 & 3.8 \\
$\mathrm{~Pb}$ & 2.2 & 0.7 & 1.5 & 1.7 & 0.9 & 1.4 & 0.3 & 0.4 & -0.4 & -0.3 & 3.7 & 0.7 & 2.5 & 1.8 \\
\hline
\end{tabular}




\section{Conclusion}

The higher content of the As and other HMs was more enriched in the rhizospheric soil than the bulk soil due to biological interactions. The HMs (i.e. As, $\mathrm{Mn}, \mathrm{Cu}, \mathrm{Ni}$ and $\mathrm{Zn}$ ) content in the rhizospheric soil was found above the permissible limits. Among them, As is extremely enriched in the soil. The higher content of HMs (i.e. As, Cr, $\mathrm{Mn}, \mathrm{Cu}, \mathrm{Ni}, \mathrm{Zn}$ and $\mathrm{Pb}$ ) in the rhizospheric soil of herbs i.e. MS and OS was observed.

\section{Acknowledgements}

We are thankful to the Italian Ministry of Education, Rome for granting the research project to Prof. E. Bontempi for the collaborative work.

\section{References}

[1] Lambrou, A., Baccarelli, A., Wright, R.O., Weisskopf, M., Bollati, V., Amarasiriwardena, C., Vokonas, P. and Schwartz, J. (2012) Arsenic Exposure and DNA Methylation among Elderly Men. Epidemiology, 23, 668-676. http://dx.doi.org/10.1097/EDE.0b013e31825afb0b

[2] Pearson, M., Jones-Hughes, T., Whear, R., Cooper, C., Peters, J., Evans, E.H. and Depledge, M. (2011) Are Interventions to Reduce the Impact of Arsenic Contamination of Groundwater on Human Health in Developing Countries Effective?: A Systematic Review Protocol. Environmental Evidence, 2, 1. http://dx.doi.org/10.1186/2047-2382-1-1

[3] Hoque, S.R. (2013) A Study on Awareness about Arsenic Pollution in Rural West Bengal. International Journal of Humanities and Social Science Invention, 2, 43-46. http://www.ijhssi.org/

[4] Singh, M.K. and Kumar, A. (2012) A Global Problem of Arsenic in Drinking Water \& Its Mitigation-A Review. International Journal of Advanced Engineering Technology, 3, 196-203.

[5] Kabay, N., Bundschuh, J., Hendry, B., Bryjak, M., Yoshizuka, K., Bhattacharya, P. and Anac, S. (2010) The Global Arsenic Problem: Challenges for Safe Water Production. CRC Press, Boca Raton.

[6] Nriagu, J. (2013) Arsenic and Global Food Security-Issues, Challenges and Research Opportunities. Global Health Perspectives, 1, 81-92. http://dx.doi.org/10.5645/ghp2013.01.015

[7] Rahman, M.A. and Hasegawa, H. (2011) High Levels of Inorganic Arsenic in Rice in Areas where Arsenic-Contaminated Water Is Used for Irrigation and Cooking. Science of Total Environment, 409, 4645-4655. http://dx.doi.org/10.1016/j.scitotenv.2011.07.068

[8] Acharyya, S.K., Ashyiya, I.D., Pandey, Y., Lahiri, S., Khongan, V.M. and Sarkar, S.K. (2001) Arsenic Contamination in Groundwater in Parts of Ambagarh Chowki-Korse Kohari Belt (Dongargarh-Kotri Rift Zone), Chhattisgrah. Geological Survey of India, Special Publication, 65, 7-18.

[9] Acharyya, S.K., Shah, B.A., Ashyiya, I.D. and Pandey, Y. (2005) Arsenic Contamination in Groundwater from Parts of Ambagarh-Chowki Block, Chhattisgarh, India: Source and Release Mechanism. Environmental Geology, 49, 148-158. http://dx.doi.org/10.1007/s00254-005-0074-3

[10] Pandey, P.K., Sharma, R., Roy, S., Roy, M. and Pandey, M. (2006) Arsenic Contamination in the Kanker District of Central-East India: Geology and Health Effects. Environmental Geochemistry and Health, 28, 409-420. http://dx.doi.org/10.1007/s10653-005-9039-4

[11] Patel, K.S., Shrivas, K., Brandt, R., Jakubowski, N., Corns, W. and Hoffmann, P. (2005) Arsenic Contamination in Water, Soil, Sediment and Rice of Central India. Environmental Geochemistry and Health, 27, 131-145. http://dx.doi.org/10.1007/s10653-005-0120-9

[12] Pierzynski, G.M., Sims, J.T. and Vance, G.F. (2000) Soils and Environmental Quality. CRC Press, London.

[13] Adriano, D.C. (2001) Trace Elements in Terrestrial Environments: Biogeochemistry, Bioavailability and Risks of Metals. Springer, New York. http://dx.doi.org/10.1007/978-0-387-21510-5

[14] Khan, S., Cao, Q., Zheng, Y.M., Huang, Y.Z. and Zhu, Y.G. (2008) Health Risks of Heavy Metals in Contaminated Soils and Food Crops Irrigated with Wastewater in Beijing, China. Environmental Pollution, 152, 686-692. http://dx.doi.org/10.1016/j.envpol.2007.06.056

[15] Kozdrój, J. and Van Elsas, J.D. (2001) Structural Diversity of Microbial Communities in Arable Soils of a Heavily Industrialised Area Determined by PCR-DGGE Finger Printing and FAME Profiling. Applied Soil Ecology, 17, 31-42. http://dx.doi.org/10.1016/S0929-1393(00)00130-X

[16] Wang, Z., Shan, X.Q. and Zhang, S. (2002) Comparison between Fractionation and Bioavailability of Trace Metals in Rhizosphere and Bulk Soils. Chemosphere, 46, 1163-1171. http://dx.doi.org/10.1016/S0045-6535(01)00206-5

[17] Hinsinger, P., Gobran, G.R., Gregory, P.J. and Wenzel, W.W. (2005) Rhizosphere Geometry and Heterogeneity Aris- 
ing from Root-Mediated Physical and Chemical Processes. The New Phytologist, 168, 293-303. http://dx.doi.org/10.1111/j.1469-8137.2005.01512.x

[18] Fitz, W.J. and Wenzel, W.W. (2002) Arsenic Transformation in the Soil-Rhizosphere-Plant System: Fundamentals and Potential Application of Phytoremediation. Journal of Biotechnology, 99, 259-278. http://dx.doi.org/10.1016/S0168-1656(02)00218-3

[19] Cheng, S. (2003) Heavy Metals in Plants and Phytoremediation. Environmental Science and Pollution Research International, 10, 335-340. http://dx.doi.org/10.1065/espr2002.11.141.3

[20] Ginneken, L.V., Meers, E., Guisson, R., Ruttens, A., Elst, K., Tack, F.M.G., Vangronsveld, J., Diels, L. and Dejonghe, W. (2007) Phytoremediation for Heavy Metal-Contaminated Soils Combined with Bioenergy Production. Journal of Environmental Engineering and Landscape management, 15, 227-236. http://www.jeelm.vgtu.lt/en

[21] Marques, A.P.G.C., Rangel, A.O.S.S. and Castro, P.M.L. (2009) Remediation of Heavy Metal Contaminated Soils: Phytoremediation as a Potentially Promising Clean-Up Technology. Critical Reviews in Environmental Science and Technology, 39, 622-654. http://dx.doi.org/10.1080/10643380701798272

[22] Badr, N., Fawzy, M. and Al-Qahtani, K.M. (2012) Phytoremediation: An Ecological Solution to Heavy-Metal-Polluted Soil and Evaluation of Plant Removal Ability. World Applied Science Journal, 16, 1292-1301.

[23] Luster, J., Göttlein, A., Nowack, B. and Sarret, G. (2009) Sampling, Defining, Characterising and Modelling the Rhizosphere-The Soil Science Tool Box. Plant and Soil, 321, 457-482. http://dx.doi.org/10.1007/s11104-008-9781-3

[24] Tomilson, D.L., Wilson, G.J., Harris, C.R. and Jeffrey, D.W. (1980) Problem in the Assessment of Heavy Metals in Estuaries and the Formation of Pollution Index. Helgolander Meeresuntersuchungen, 33, 566-575. http://dx.doi.org/10.1007/BF02414780

[25] Sinex, S.A. and Helz, G.R. (1981) Regional Geochemistry of Trace Elements in Chesapeake Bay Sediments. Environmental Geology, 3, 315-323. http://dx.doi.org/10.1007/BF02473521

[26] Choudhary, A., Sharma, R., Nagar, M. and Mohsin, M. (2011) Transition Metal Complexes with N, S Donor Ligands as Synthetic Antioxidants: Synthesis, Characterization and Antioxidant Activity. Journal of Enzyme Inhibition and Medicinal Chemistry, 26, 394-403. http://dx.doi.org/10.3109/14756366.2010.518966

[27] Ganguly, P., Gupta, A.K., Majumder, U.K. and Ghosal, S. (2009) The Chemistry behind the Toxicity of Black Nightshade, Solanum Nigrum and the Remedy. Pharmacologyonline, 1, 705-723.

[28] Rudnick, R.L. and Gao, S. (2003) The Composition of the Continental Crust. In: Holland, H.D. and Turekian, K.K., Eds., Treatise on Geochemistry, Vol. 3, The Crust, Elsevier-Pergamon, Oxford, 1-64. http://dx.doi.org/10.1016/b0-08-043751-6/03016-4

[29] Lacatusu, R. (2000) Appraising Levels of Soil Contamination and Pollution with Heavy Metals. European Soil Bureau Research Report No. 4, 93-402.

[30] Livingston, J.V. (2005) Agriculture and Soil Pollution: New Research. Nova Science Publishers, New York.

[31] Finnegan, P.M. and Chen, W. (2012) Arsenic Toxicity: The Effects on Plant Metabolism. Frontiers in Physiology, 3, 182. http://dx.doi.org/10.3389/fphys.2012.00182 